\title{
Determination of Optimal Fibre Reinforcement Parameters for Self-Compacting Concretes
}

\author{
Daniyar AKHMETOV, Aleksej ANISKIN, Yelbek UTEPOV*, Yelena ROOT, Goran KOZINA
}

\begin{abstract}
The article presents the results of the conducted study of the possibility and expediency of disperse reinforcement of self-compacting concrete (SCC) in order to improve the physical and technical indicators and the analysis of deformative properties of SCC using fiber. For satisfaction of requests from factories-manufacturers of SCC concerning the improvement of physical-mechanical and operational properties of SCC and identification of basic dependences that can be used by them in change of technological regulations for this type of concrete, theoretical and empirical methods of research were used. The results of these studies indicate that the introduction of a certain amount of polypropylene fiber improves the physical-technical and deformation characteristics of the operating SCC compounds, increasing the bending strength and reducing the size of shrinkage deformations. The efficiency of bulk fibre reinforcement with low-modulus polypropylene fibre of SCC mixtures has been experimentally proven in production. From the deduced mathematical dependences practical recommendations on an optimum choice of the sizes and the fibre content in SCC mixtures are proposed to obtain an optimum price-quality ratio, particularly when performing concrete works in summer time.
\end{abstract}

Keywords: bending strength; deformation; mathematical modeling; polypropylene fiber; self-compacting concrete

\section{INTRODUCTION}

Modern construction demands a variety of construction materials with different sets of properties. One of the promising areas of modern concrete science is improving the technology of self-compacting concrete (SCC)-a material that is increasingly being used in the construction industry of the Republic of Kazakhstan.

High rheological properties of the SCC the ability to compact under the influence of its own weight, filling the form even in densely reinforced structures and the elimination of vibration, significantly improve the quality of concrete structures and provide significant advantages for architectural solutions and the construction process [1, 2]. Some of the benefits are obvious and measurable, while others are not always immediately apparent. There are at least three main advantages that SCC technology brings to the concrete construction industry: optimizing labor costs and, accordingly, increasing productivity, expanding opportunities for architectural design, as well as improving working conditions by abandoning traditional paving with the use of vibration compaction [3].

SCC is the object of study of material scientists from all over the world. In recent years, construction materials science has paid increasing attention to the development of SCC compositions with improved physical-technical, operational properties and durability [4-6]. The composition of SCC constituents differs from that of conventional concrete constituents. SCC is usually characterized by an increased content of sand and binder (cement and aggregates). A properly manufactured SCC with the correct proportions of the constituents is usually more homogeneous, and its properties are less variable than those of conventional concrete.

Relevance of this study lies in the fact that the works devoted to the study of the properties of fiber-reinforced SCC in order to improve the physical and technical properties and the analysis of deformation properties of SCC using fiber are very few. These works mainly consider the possibility of reinforcing the SCC by a high-modular steel fiber with the reflection of the solution of one particular problem, for example the solution of the problem of brittle fracture of high strength concrete [7, 8].
Manufacturers of SCC, in their turn, request the science to study the possibilities of improving the physicalmechanical and operational properties of SCC and determine the main dependencies that can be used by them in changing the technological regulations for this type of concrete [8].

Having considered the requirements put forward by the manufacturers of SCC, the group of researchers came up with the idea that it is necessary to consider the possibility of combining the useful properties of two types of concrete: Self-compacting concrete and composite material consisting of a cement matrix (dense or porous, with or without aggregate) with an even or given distribution over its volume of oriented or chaotically arranged discrete fibres of different origin. Currently, for disperse reinforcement of fibre concrete used metal (mostly steel) and non-metallic (mineral, polymer, etc.) high and low-modulus fibers of various shapes, lengths and cross sections. Fibroconcretes have increased deformation properties, first of all, flexural strength at bending, low shrinkage deformations, and high resistance to abrasion. Having carried out the review of the international literature on the chosen subject, having got acquainted with the last works of the known scientists in the field of building materials science on the study of these concretes and leaning on their own rich experience, the members of the research group have come to the conclusion that at the moment there are all preconditions proving the possibility of creation of a SCC with high physical and technical characteristics, based on the successful application of various production wastes [9].

The experience accumulated by the members of the research team of NIISTROMPRJOECT, LLP during several years of inspection works on construction sites and factories producing reinforced concrete structures, as well as systematic research and testing of products and structures in the process of operation show that it is very important not only to ensure the specified properties of concrete, but also to preserve them during the entire period of operation of the building or structure, in this regard, the research team has formed the following series of serious tasks: 
- study of the influence of fiber reinforcement parameters on the workability of SCC, description of rheological properties of fiber concrete mixtures, as well as the establishment of mathematical dependencies reflecting the most important operational indicator of this type of concrete from the perspective of practical application;

- study of factors estimating the influence of the size and quantity of reinforcing fibers, in particular, the flexural strength of concrete at bending in order to improve the deformation and operational properties of concrete working under appropriate loads (Fig. 1a), as well as the mathematical approach to predict the properties of SCC with the use of bulk fiber reinforcement;

- determination of dependence of drying shrinkage value on fiber reinforcement parameters and building of mathematical model aimed at reducing the risk of cracks, potholes and dents in concrete (Fig. 1b) associated with increased shrinkage deformations of concrete under conditions of sharp-continental dry and hot climate of Kazakhstan in summer (at ambient temperature between 30 and $45^{\circ} \mathrm{C}$ ).

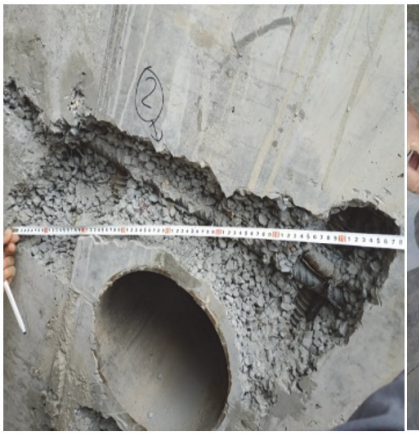

(a)

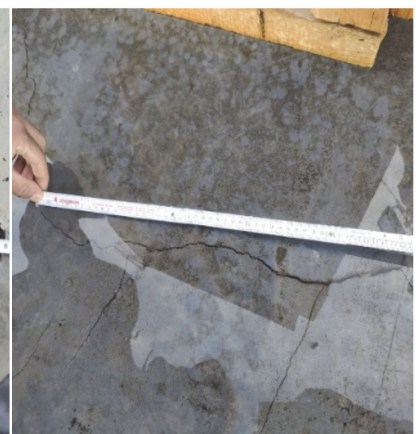

(b)
Figure 1 Destruction of concrete during improper operation (a) and cracks resulting from concrete shrinkage in the summertime (b)

It is necessary to notice that in the solution of these problems the system approach allowing to predict and directionally regulate properties of this material depending on the problems put before researchers is necessary [10].

Based on the materials of the 2nd International Conference on Composite Materials FIBROMIX 2019 held in St. Petersburg, one of the ways to improve the physical, technical and operational characteristics of concrete is the introduction of polymeric low-modulus fiber. The use of this material allows increasing the flexural strength of cement stone, which provides higher flexural strength in flexure and crack resistance, as well as other characteristics of cement-based building materials, such as mixture homogeneity and reduced volume shrinkage [11]. It is recommended to use polypropylene fiber in fiber concrete technology to reduce the segregation of mixtures, increase water resistance, frost resistance, corrosion resistance, impact strength, abrasion resistance. Furthermore, polypropylene fiber differs in corrosion resistance in comparison with steel fiber, which can easily be corroded in alkaline concrete condition at $P H>7$. At the same time, there is evidence of a slight decrease in the compressive strength of polypropylene fibre cement materials.

When choosing this type of fiber for research also taken into account is the economic aspect of the relevance of research, that the required amount of polymer fiber is much cheaper than metal fiber for the same volume.

Also, polypropylene fiber reinforcement makes the concrete surface stronger, improves overall water resistance, the material becomes resistant to chemical compounds [12].

\section{METHODS \\ 2.1 Materials}

Theoretical and empirical research methods are used in this study. Theoretical research was built on an axiomatic level, in order to build a system of derivative assumptions based on the fundamental laws of modern concrete science and physicolloid chemistry, as well as analysis and modeling for a detailed study and comparison with previously obtained by the research team and implemented in production compositions of SCC mixtures, including the use of fiber reinforcement [13], as well as determining the direction of work, focusing on the use of low-module reinforcement fibers of a certain size. The empirical studies were aimed at experimental confirmation of the theoretical hypothesis of the possibility of applying fibre reinforcement in SCC and interpretation of the results as a mathematical model. At statistical processing of results of experiment by means of mathematical modelling the second order rotatable design was applied, as in comparison with orthogonal designs it provides reception of adequate models with the greatest probability.

This study was conducted in five stages, each of which was aimed at a specific task (Fig. 2).

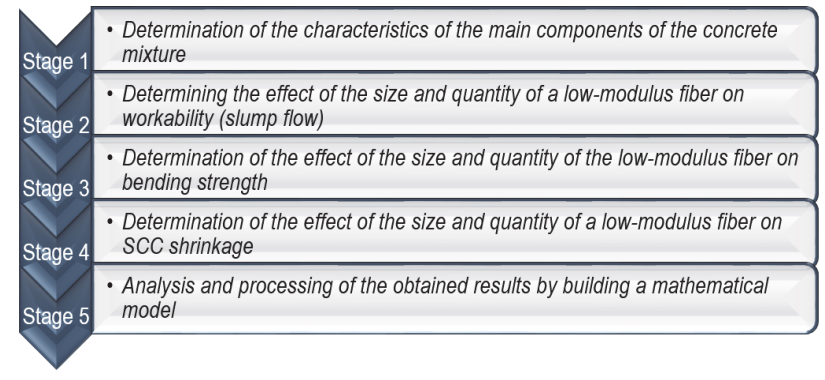

Figure 2 Study workflow

The research methodology was aimed at implementing a numerous series of experimental mixtures based on mathematical planning of the experiment by varying the number and size of low-modulus fiber and processing the results of the obtained rheological and physical-technical characteristics of the concrete mixture, as well as strength and deformation indices of the final SCC conglomerate. All the studies and tests were conducted in accordance with the normative documentation in force on the territory of the Republic of Kazakhstan.

\subsection{Determination of the Characteristics of Concrete Mixture Components}

Cement M400D20 (CEM II/A-S 42,5 N according to [14]) produced by Semey Cement Plant, LLP (Semey, Kazakhstan) was taken as a binder for investigated concrete mixtures. To confirm the compliance of the selected binder with the requirements of [15] a number of 
tests were conducted. The methods specified in these standards allow to determine the following parameters of the building material:

1) Grinding fineness. For the examined binder the grinding fineness amounted to $94,4 \%$ that complies with the requirements of [15].

2) Normal density and setting time of cement dough. For the examined binder the normal density amounted to $27,30 \%$. The setting started after 2 hours and 11 minutes and the end of the setting started after 4 hours and 10 minutes from the moment of setting. These indicators are included in the normalized range [16].

3) Compression and bending strength. During the determination of strength characteristics, the binder under study at the age of 28 days showed the bending strength of $5,6 \mathrm{MPa}$ and the compression strength of $42,4 \mathrm{MPa}$. These indicators are included in the normalized range [17].

Sand from the manufacturer Mark, LLP (Almaty region, Kazakhstan) complying with the [18] was used for the tests. According to this standard, sands with a maximum amount of dusty and clayey inclusions for high coarseness groups, coarse and medium in the amount of 3\% can be used as a fine aggregate for heavy concretes, under the definition of which the SCC can also be included [18]. However, according to the results of laboratory and production tests 19], to obtain satisfactory characteristics of the concrete mixture and the final conglomerate of the SCC it is necessary to use sand, in which the amount of dusty inclusions does not exceed $1,5 \%$. The test to determine the number of dusty and clayey inclusions of the sand under consideration was carried out by the method of soaking in accordance with the requirements of [20]. According to the test results, the content of dust and clay inclusions in the studied sand was $1,08 \%$. Also, according to [20] by sifting and determining the grain composition of the aggregate, the particle size modulus of the studied sand was determined, which amounted to 2,6. These parameters are acceptable to enable using the studied aggregate both in heavy concretes and in SCC in particular.

Crushed stone of $5-10 \mathrm{~mm}$ and $10-20 \mathrm{~mm}$ fractions produced by Kentas, LLP (Almaty region, Kazakhstan) composed of gravel and boulders having 1 group by the content of grains of lamellar (needle shape) was taken as a large aggregate. Its granulometric composition is given in Tab. 1 below. This aggregate meets the requirements of [21] for crushed stone from dense rocks used as an aggregate for heavy concrete, including SCC.

Table 1 Specifications of AR Premium AH hyperplasticizer

\begin{tabular}{|c|c|c|c|c|}
\hline $\begin{array}{c}\text { Diameter of holes } \\
\text { in the control } \\
\text { sieves / mm }\end{array}$ & $d$ & $0,5(d+D)$ & $D$ & $1,25 \mathrm{D}$ \\
\hline \multicolumn{4}{|c|}{ Separation results. Fraction $5-10 \mathrm{~mm}$} \\
\hline $\begin{array}{c}\text { Normalized total } \\
\text { sieve residue, \% by } \\
\text { weight }\end{array}$ & $90-100$ & $30-60$ & until 10 & until 0,5 \\
\hline $\begin{array}{c}\text { Actual result, \% by } \\
\text { mass }\end{array}$ & 98,5 & 59,43 & 8,05 & 0,38 \\
\hline \multicolumn{5}{|c|}{ Separation results. Fraction $10-20 \mathrm{~mm}$} \\
\hline $\begin{array}{c}\text { Normalized total } \\
\text { sieve residue, \% by } \\
\text { weight }\end{array}$ & $90-100$ & $30-60$ & until 10 & until 0,5 \\
\hline $\begin{array}{c}\text { Actual result, \% by } \\
\text { mass }\end{array}$ & 99,98 & 58,61 & 9,54 & 0,42 \\
\hline
\end{tabular}

As hyperplasticizer the chemical additive on the basis of ethers of polycarboxylates of 2 generation AR Premium AH produced by Ariranggroup, LLP, Nur-Sultan, with the following characteristics was used (Tab. 2):

Table 2 Specifications of AR Premium AH hyperplasticizer

\begin{tabular}{|c|c|}
\hline Indicator & Indicator value \\
\hline Appearance & $\begin{array}{c}\text { Homogeneous liquid of light yellow } \\
\text { color }\end{array}$ \\
\hline Density at $25^{\circ} \mathrm{C} / \mathrm{kg} / \mathrm{m}^{3}$ & $1030-1070$ \\
\hline Hydrogen index, $\mathrm{pH}$ & 4 \\
\hline $\begin{array}{c}\text { Cl-ions content, no more } \\
\text { than }\end{array}$ & 0,1 \\
\hline
\end{tabular}

For bulk reinforcement, low-modulus polypropylene fiber of various lengths of FibroLux LLC, St. Petersburg, with the following characteristics was used in the research (Tab. 3):

Table 3 Technical specifications of polypropylene fiber

\begin{tabular}{|c|c|c|}
\hline Indicator name & Normative value & Actual value \\
\hline Chemical formula & Polypropylene & Polypropylene \\
\hline Type & Monofiber & Monofiber \\
\hline Fiber length & $6-15 \mathrm{~mm}$ & Compies \\
\hline Fiber diameter & $18-21 \mu \mathrm{m}$ & $20 \mu \mathrm{m}$ \\
\hline Shape & Round & Round \\
\hline Surface & $\begin{array}{c}\text { Processed with a } \\
\text { special compound } \\
\text { that facilitates } \\
\text { dispersion and } \\
\text { adhesion to cement } \\
\text { mortar }\end{array}$ & $\begin{array}{c}\text { Processed by Silastol } \\
\text { CUT 70 }\end{array}$ \\
\hline Density & $0,91 \mathrm{~g} / \mathrm{cm}^{3}$ & $0,91 \mathrm{~g} / \mathrm{cm}^{3}$ \\
\hline Fiber frequency & $19,8 \mathrm{million} / \mathrm{kg}$ & Compies \\
\hline $\begin{array}{c}\text { Flexural strength } \\
\text { (medium) }\end{array}$ & $320-600 \mathrm{MPa}$ & Compies \\
\hline Young's modulus & $3500-3900 \mathrm{MPa} 10^{-6}$ & Compies \\
\hline Color & White & White \\
\hline
\end{tabular}

\subsection{Determination of the Effect of the Size and Quantity of a Low-Modulus Fiber on Slump Flow}

In this test, the SCC of class B35 without any fibre reinforcement was taken as the control concrete of the factories (Tab. 4).

\begin{tabular}{|c|c|} 
Table 4 SCC composition (control) \\
\begin{tabular}{|c|c|}
\hline Composition & Value \\
\hline $\mathrm{W} / \mathrm{C}$ & 0,4 \\
\hline Cement $/ \mathrm{kg} / \mathrm{m}^{3}$ & 540 \\
\hline Sand $/ \mathrm{kg} / \mathrm{m}^{3}$ & 944 \\
\hline Crushed stone $, 5-10 \mathrm{~mm}, \mathrm{~kg} / \mathrm{m}^{3}$ & 625 \\
\hline Crushed stone, $10-20 \mathrm{~mm}, \mathrm{~kg} / \mathrm{m}^{3}$ & 175 \\
\hline Additive $/ \mathrm{kg} / \mathrm{m}^{3}$ & 6,5 \\
\hline Microsilica $/ \mathrm{kg} / \mathrm{m}^{3}$ & 54 \\
\hline
\end{tabular}
\end{tabular}

We carried out the slump flow tests in stages, starting with the control composition, classifying the mixtures in terms of workability [22]. With each subsequent test, a low-modulus polypropylene fibers of $6,9,12$ and $15 \mathrm{~mm}$ in size were added stepwise by $0,5 \mathrm{~kg}$ per $1 \mathrm{~m}^{3}$, up to a consumption of $2 \mathrm{~kg}$ per $1 \mathrm{~m}^{3}$ for each composition. According to [23], further increase in the amount of fiber is not expedient, as it leads to a sharp decrease in the physical and technical characteristics of the mixture and is economically inexpedient. The tested compositions are shown in Tab. 5.

As a result of processing the received data of the slump flow by the method of mathematical planning of the 
experiment, the model of dependence of SCC's workability on the size and amount of fibre in the composition of the mixture (Tab. 6) was obtained (note, when building the model for clarity of the data, the amount of fibre was recalculated in $\%$ of the cement weight).

Mathematical model of the effect of fibre length $\left(X_{1}\right)$ and fibre content $\left(X_{2}\right)$ onto the slum flow $\left(Y_{3}\right)$ may be expressed as $Y_{3}=60,643-1,616 X_{2}+26,25 X_{1}^{2}+26,06 X_{2}^{2}$, whereas the graphical illustration may be represented as follows (Fig. 3).

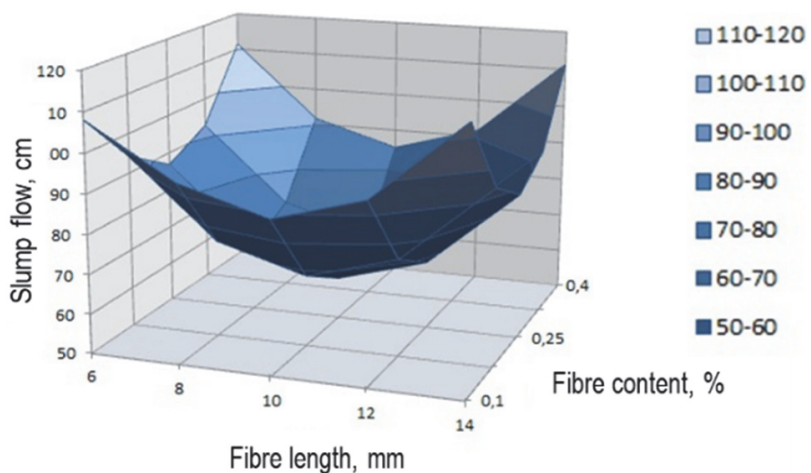

Fibre length, $\mathrm{mm}$

Figure 3 Mathematical model: slump flow vs. fiber content and size

Table 5 Tested compositions

\begin{tabular}{|c|c|c|c|c|c|c|c|c|c|}
\hline \multirow[b]{2}{*}{ No } & \multirow[b]{2}{*}{ Composition name } & \multicolumn{8}{|c|}{ Consumption of components, $\mathrm{kg} / \mathrm{m}^{3}$} \\
\hline & & 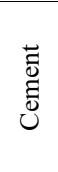 & 荧 & 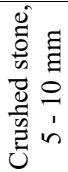 & 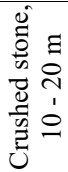 & $\stackrel{D}{:}$ & 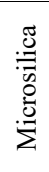 & $\stackrel{0}{0}$ & $\begin{array}{l}\dot{\bar{d}} \\
\frac{\vec{J}}{3} \\
\vec{B}\end{array}$ \\
\hline 0.1 & Control composition & 540 & 944 & 625 & 175 & 6,5 & 54 & 0 & 260 \\
\hline 1.1 & Fibre $6 \mathrm{~mm}$, consumption $0,5 \mathrm{~kg} / \mathrm{m}^{3}$ & 540 & 944 & 625 & 175 & 6,5 & 54 & 0,5 & 260 \\
\hline 1.2 & Fibre $6 \mathrm{~mm}$, consumption $1 \mathrm{~kg} / \mathrm{m}^{3}$ & 540 & 944 & 625 & 175 & 6,5 & 54 & 1 & 260 \\
\hline 1.3 & Fibre $6 \mathrm{~mm}$, consumption $1,5 \mathrm{~kg} / \mathrm{m}^{3}$ & 540 & 944 & 625 & 175 & 6,5 & 54 & 1,5 & 260 \\
\hline 1.4 & Fibre $6 \mathrm{~mm}$, consumption $2 \mathrm{~kg} / \mathrm{m}^{3}$ & 540 & 944 & 625 & 175 & 6,5 & 54 & 2 & 260 \\
\hline 2.1 & Fibre $9 \mathrm{~mm}$, consumption $0,5 \mathrm{~kg} / \mathrm{m}^{3}$ & 540 & 944 & 625 & 175 & 6,5 & 54 & 0,5 & 260 \\
\hline 2.2 & Fibre $9 \mathrm{~mm}$, consumption $1 \mathrm{~kg} / \mathrm{m}^{3}$ & 540 & 944 & 625 & 175 & 6,5 & 54 & 1 & 260 \\
\hline 2.3 & Fibre $9 \mathrm{~mm}$, consumption $1,5 \mathrm{~kg} / \mathrm{m}^{3}$ & 540 & 944 & 625 & 175 & 6,5 & 54 & 1,5 & 260 \\
\hline 2.4 & Fibre $9 \mathrm{~mm}$, consumption $2 \mathrm{~kg} / \mathrm{m}^{3}$ & 540 & 944 & 625 & 175 & 6,5 & 54 & 2 & 260 \\
\hline 3.1 & Fibre $12 \mathrm{~mm}$, consumption $0,5 \mathrm{~kg} / \mathrm{m}^{3}$ & 540 & 944 & 625 & 175 & 6,5 & 54 & 0,5 & 260 \\
\hline 3.2 & Fibre $12 \mathrm{~mm}$, consumption $1 \mathrm{~kg} / \mathrm{m}^{3}$ & 540 & 944 & 625 & 175 & 6,5 & 54 & 1 & 260 \\
\hline 3.3 & Fibre $12 \mathrm{~mm}$, consumption $1,5 \mathrm{~kg} / \mathrm{m}^{3}$ & 540 & 944 & 625 & 175 & 6,5 & 54 & 1,5 & 260 \\
\hline 3.4 & Fibre $12 \mathrm{~mm}$, consumption $2 \mathrm{~kg} / \mathrm{m}^{3}$ & 540 & 944 & 625 & 175 & 6,5 & 54 & 2 & 260 \\
\hline 4.1 & Fibre $15 \mathrm{~mm}$, consumption $0,5 \mathrm{~kg} / \mathrm{m}^{3}$ & 540 & 944 & 625 & 175 & 6,5 & 54 & 0,5 & 260 \\
\hline 4.2 & Fibre $15 \mathrm{~mm}$, consumption $1 \mathrm{~kg} / \mathrm{m}^{3}$ & 540 & 944 & 625 & 175 & 6,5 & 54 & 1 & 260 \\
\hline 4.3 & Fibre $15 \mathrm{~mm}$, consumption $1,5 \mathrm{~kg} / \mathrm{m}^{3}$ & 540 & 944 & 625 & 175 & 6,5 & 54 & 1,5 & 260 \\
\hline 4.4 & Fibre $15 \mathrm{~mm}$, consumption $2 \mathrm{~kg} / \mathrm{m}^{3}$ & 540 & 944 & 625 & 175 & 6,5 & 54 & 2 & 260 \\
\hline
\end{tabular}

Table 6 Dependence of slump flow on fiber content and length

\begin{tabular}{|c|c|c|c|}
\hline No & Composition name & Average density of the mixture $/ \mathrm{kg} / \mathrm{m}^{3}$ & Slump flow $/ \mathrm{cm}$ \\
\hline 0.1 & Control composition & 2395 & 70 \\
\hline 1.1 & Fibre $6 \mathrm{~mm}$, consumption $0,5 \mathrm{~kg} / \mathrm{m}^{3}$ & 2402 & 67 \\
\hline 1.2 & Fibre $6 \mathrm{~mm}$, consumption $1 \mathrm{~kg} / \mathrm{m}^{3}$ & 2299 & 65 \\
\hline 1.3 & Fibre $6 \mathrm{~mm}$, consumption $1,5 \mathrm{~kg} / \mathrm{m}^{3}$ & 2268 & 63 \\
\hline 1.4 & Fibre $6 \mathrm{~mm}$, consumption $2 \mathrm{~kg} / \mathrm{m}^{3}$ & 2249 & 60 \\
\hline 2.1 & Fibre $9 \mathrm{~mm}$, consumption $0,5 \mathrm{~kg} / \mathrm{m}^{3}$ & 2320 & 64 \\
\hline 2.2 & Fibre $9 \mathrm{~mm}$, consumption $1 \mathrm{~kg} / \mathrm{m}^{3}$ & 2294 & 62 \\
\hline 2.3 & Fibre $9 \mathrm{~mm}$, consumption $1,5 \mathrm{~kg} / \mathrm{m}^{3}$ & 2280 & 60 \\
\hline 2.4 & Fibre $9 \mathrm{~mm}$, consumption $2 \mathrm{~kg} / \mathrm{m}^{3}$ & 2253 & 57 \\
\hline 3.1 & Fibre $12 \mathrm{~mm}$, consumption $0,5 \mathrm{~kg} / \mathrm{m}^{3}$ & 2351 & 63 \\
\hline 3.2 & Fibre $12 \mathrm{~mm}$, consumption $1 \mathrm{~kg} / \mathrm{m}^{3}$ & 2343 & 60 \\
\hline 3.3 & Fibre $12 \mathrm{~mm}$, consumption $1,5 \mathrm{~kg} / \mathrm{m}^{3}$ & 2298 & 58 \\
\hline 3.4 & Fibre $12 \mathrm{~mm}$, consumption $2 \mathrm{~kg} / \mathrm{m}^{3}$ & 2278 & 57 \\
\hline 4.1 & Fibre $15 \mathrm{~mm}$, consumption $0,5 \mathrm{~kg} / \mathrm{m}^{3}$ & 2351 & 62 \\
\hline 4.2 & Fibre $15 \mathrm{~mm}$, consumption $1 \mathrm{~kg} / \mathrm{m}^{3}$ & 2328 & 60 \\
\hline 4.3 & Fibre $15 \mathrm{~mm}$, consumption $1,5 \mathrm{~kg} / \mathrm{m}^{3}$ & 2315 & 59 \\
\hline 4.4 & Fibre $15 \mathrm{~mm}$, consumption $2 \mathrm{~kg} / \mathrm{m}^{3}$ & 2310 & 57 \\
\hline
\end{tabular}

\subsection{Determination of the Effect of the Size and Quantity of Low-Modulus Fibers on Bending}

In the course of the bending test, the specimens were shaped in accordance with [24] from a mixture of control composition and then from each subsequent test composition (Tab. 5).

Further, when the specimens reached the design age of 28 days, bending flexural tests were performed according to [25] (Fig. 4). 


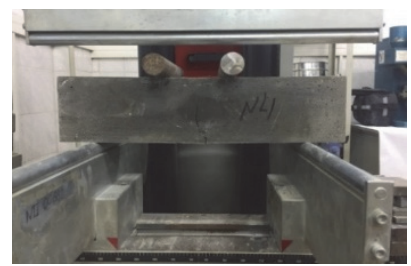

Figure 4 Bending test of beam

The flexural strength of concrete in bending was calculated with an accuracy of 0,01 MPa using the Eq. (1): where, $F$ - breaking load, $\mathrm{N} ; a, b, l$ - width, height of prism cross section and distance between supports respectively during bending flexural tests, $\mathrm{mm} ; \delta$ - scaling factors to convert the concrete strength to concrete strength in specimens of base size and shape.

After calculations of specimen flexural strength at bending by the method of mathematical planning of the experiment, the model of dependence of the effect of length and content of low-modulus polypropylene fiber on bending strength was obtained (Tab. 7).

$$
R_{b t}=\delta \frac{F l}{a b^{2}}
$$

Table 7 Dependence of bending strength on fiber content and length

\begin{tabular}{|c|c|c|c|}
\hline No & Composition name & Average density, 28 days $/ \mathrm{kg} / \mathrm{m}^{3}$ & Bending strength, 28 days / $\mathrm{MPa}$ \\
\hline 0.1 & Control composition & 2317,33 & 5,036 \\
\hline 1.1 & Fibre $6 \mathrm{~mm}$, consumption $0,5 \mathrm{~kg} / \mathrm{m}^{3}$ & 2310,00 & 4,382 \\
\hline 1.2 & Fibre $6 \mathrm{~mm}$, consumption $1 \mathrm{~kg} / \mathrm{m}^{3}$ & 2298,00 & 4,847 \\
\hline 1.3 & Fibre $6 \mathrm{~mm}$, consumption $1,5 \mathrm{~kg} / \mathrm{m}^{3}$ & 2278,33 & 4,789 \\
\hline 1.4 & Fibre $6 \mathrm{~mm}$, consumption $2 \mathrm{~kg} / \mathrm{m}^{3}$ & 2280,67 & 4,548 \\
\hline 2.1 & Fibre $9 \mathrm{~mm}$, consumption $0,5 \mathrm{~kg} / \mathrm{m}^{3}$ & 2260,00 & 4,611 \\
\hline 2.2 & Fibre $9 \mathrm{~mm}$, consumption $1 \mathrm{~kg} / \mathrm{m}^{3}$ & 2232,33 & 5,192 \\
\hline 2.3 & Fibre $9 \mathrm{~mm}$, consumption $1,5 \mathrm{~kg} / \mathrm{m}^{3}$ & 2257,33 & 5,043 \\
\hline 2.4 & Fibre $9 \mathrm{~mm}$, consumption $2 \mathrm{~kg} / \mathrm{m}^{3}$ & 2265,33 & 4,931 \\
\hline 3.1 & Fibre $12 \mathrm{~mm}$, consumption $0,5 \mathrm{~kg} / \mathrm{m}^{3}$ & 2274,33 & 5,075 \\
\hline 3.2 & Fibre $12 \mathrm{~mm}$, consumption $1 \mathrm{~kg} / \mathrm{m}^{3}$ & 2251,33 & 5,175 \\
\hline 3.3 & Fibre $12 \mathrm{~mm}$, consumption $1,5 \mathrm{~kg} / \mathrm{m}^{3}$ & 2227,33 & 4,746 \\
\hline 3.4 & Fibre $12 \mathrm{~mm}$, consumption $2 \mathrm{~kg} / \mathrm{m}^{3}$ & 2206,33 & 4,482 \\
\hline 4.1 & Fibre $15 \mathrm{~mm}$, consumption $0,5 \mathrm{~kg} / \mathrm{m}^{3}$ & 2293,00 & 5,163 \\
\hline 4.2 & Fibre $15 \mathrm{~mm}$, consumption $1 \mathrm{~kg} / \mathrm{m}^{3}$ & 2301,00 & 5,567 \\
\hline 4.3 & Fibre $15 \mathrm{~mm}$, consumption $1,5 \mathrm{~kg} / \mathrm{m}^{3}$ & 2275,00 & 5,465 \\
\hline 4.4 & Fibre $15 \mathrm{~mm}$, consumption $2 \mathrm{~kg} / \mathrm{m}^{3}$ & 2232,33 & 5,223 \\
\hline
\end{tabular}

Mathematical model of the effect of fibre length $\left(X_{1}\right)$ and fibre content $\left(X_{2}\right)$ onto the SCC bending strength $\left(Y_{1}\right)$ may be expressed as $Y_{1}=4,86+2,14 X_{1}^{2}+2,02 X_{2}^{2}$, whereas the graphical illustration may be represented as follows (Fig. 5).

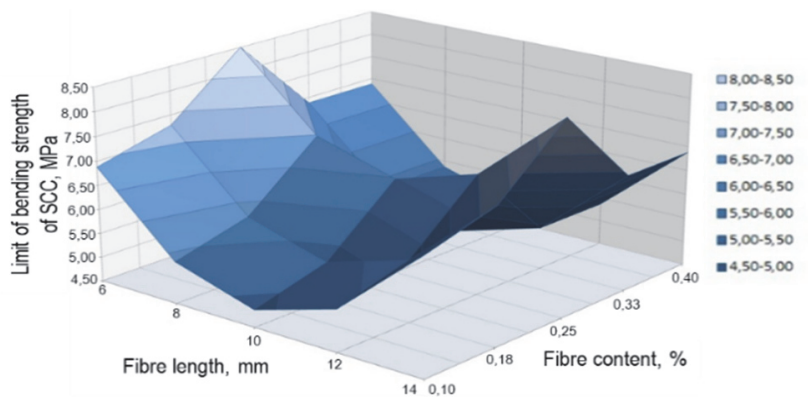

Figure 5 Mathematical model: bending strength vs. fibre content and size

\subsection{Determination of the Effect of the Size and Quantity of a Low-Modulus Fiber on Scc Shrinkage}

The shrinkage deformation was determined on prismatic specimens of $100 \times 100 \times 400 \mathrm{~mm}$ considering the maximum aggregate size in accordance with [25]. When determining shrinkage deformations, a seies should consist of at least 3 prism specimens, which according to the adopted algorithm were formed from a mixture of control composition and then from each subsequent tested composition. Then, after 24 hours of storage in a humid environment, the specimens were demoulded and then tested in accordance with [26] (Fig. 6).

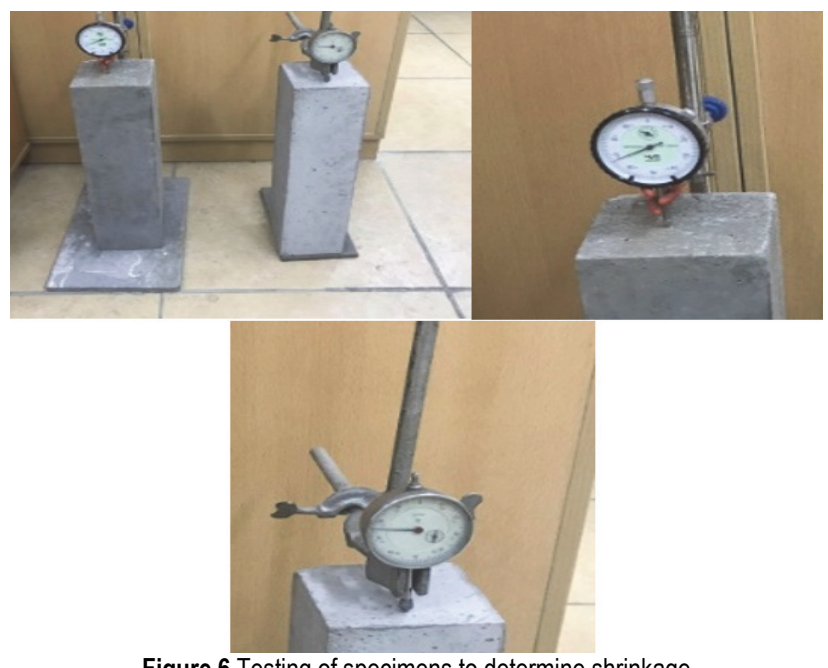

Figure 6 Testing of specimens to determine shrinkage

According to the results of determining the relative value of deformations of shrinkage of specimens, the average value of relative deformations of shrinkage for a series of specimens is determined by Eq. (2):

$\bar{\varepsilon}(t)=\frac{\sum_{i-1}^{n} \varepsilon_{1}(t)}{n}$ 
where, $\bar{\varepsilon}(t)$ average value of the relative shrinkage deformation for each specimen in the series; $n$ number of specimens in the series.

Further, the mean value of the relative shrinkage deformation (Tab. 8) was converted as a percentage of the specimen size and used to build a mathematical model of the dependence of shrinkage deformations of SCC on the length and content of a low-modulus polypropylene fiber in the composition.

Table 8 Dependence of the shrinkage deformation on fiber content and length
\begin{tabular}{|c|c|c|}
\hline No & Composition name & $\begin{array}{c}\text { Drying shrinkage } \\
/ \mathrm{mm} / \mathrm{m}\end{array}$ \\
\hline 0.1 & Control composition & $-0,23$ \\
\hline 1.1 & Fibre $6 \mathrm{~mm}$, consumption $0,5 \mathrm{~kg} / \mathrm{m}^{3}$ & $-0,213$ \\
\hline 1.2 & Fibre $6 \mathrm{~mm}$, consumption $1 \mathrm{~kg} / \mathrm{m}^{3}$ & $-0,207$ \\
\hline 1.3 & Fibre $6 \mathrm{~mm}$, consumption $1,5 \mathrm{~kg} / \mathrm{m}^{3}$ & $-0,201$ \\
\hline 1.4 & Fibre $6 \mathrm{~mm}$, consumption $2 \mathrm{~kg} / \mathrm{m}^{3}$ & $-0,194$ \\
\hline 2.1 & Fibre $9 \mathrm{~mm}$, consumption $0,5 \mathrm{~kg} / \mathrm{m}^{3}$ & $-0,187$ \\
\hline 2.2 & Fibre $9 \mathrm{~mm}$, consumption $1 \mathrm{~kg} / \mathrm{m}^{3}$ & $-0,165$ \\
\hline 2.3 & Fibre $9 \mathrm{~mm}$, consumption $1,5 \mathrm{~kg} / \mathrm{m}^{3}$ & $-0,157$ \\
\hline 2.4 & Fibre $9 \mathrm{~mm}$, consumption $2 \mathrm{~kg} / \mathrm{m}^{3}$ & $-0,148$ \\
\hline 3.1 & Fibre $12 \mathrm{~mm}$, consumption $0,5 \mathrm{~kg} / \mathrm{m}^{3}$ & $-0,139$ \\
\hline 3.2 & Fibre $12 \mathrm{~mm}$, consumption $1 \mathrm{~kg} / \mathrm{m}^{3}$ & $-0,13$ \\
\hline 3.3 & Fibre $12 \mathrm{~mm}$, consumption $1,5 \mathrm{~kg} / \mathrm{m}^{3}$ & $-0,1$ \\
\hline 3.4 & Fibre $12 \mathrm{~mm}$, consumption $2 \mathrm{~kg} / \mathrm{m}^{3}$ & $-0,09$ \\
\hline 4.1 & Fibre $15 \mathrm{~mm}$, consumption $0,5 \mathrm{~kg} / \mathrm{m}^{3}$ & $-0,078$ \\
\hline 4.2 & Fibre $15 \mathrm{~mm}$, consumption $1 \mathrm{~kg} / \mathrm{m}^{3}$ & $-0,067$ \\
\hline 4.3 & Fibre $15 \mathrm{~mm}$, consumption $1,5 \mathrm{~kg} / \mathrm{m}^{3}$ & $-0,055$ \\
\hline 4.4 & Fibre $15 \mathrm{~mm}$, consumption $2 \mathrm{~kg} / \mathrm{m}^{3}$ & $-0,021$ \\
\hline
\end{tabular}

Mathematical model of the effect of fibre length $\left(X_{1}\right)$ and fibre content $\left(X_{2}\right)$ onto shrinkage deformations of SCC $\left(Y_{2}\right)$ may be expressed as the following equation $Y_{2}=$ $0,1381-0,028 X_{1}+0,058 X_{1}^{2}+0,061 X_{2}^{2}$, whereas the graphical illustration may be represented as follows (Fig. 7).

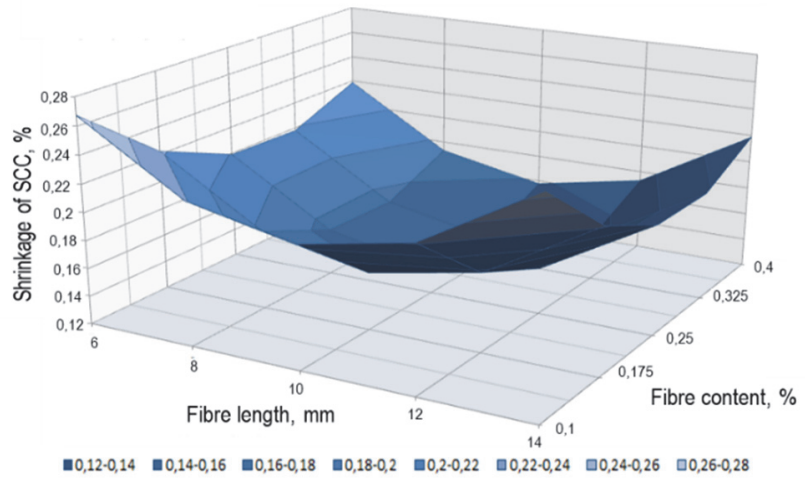

Figure 7 Mathematical model: shrinkage deformation vs. fiber content and size

\section{RESULTS AND DISCUSSION}

The results of the tests conducted, reflected in the mathematical dependences of the slump flow on the parameters of fiber-reinforcement, show the decline of workability of the mixtures with fiber-reinforcement compared to the control composition, which is in compliance with [27]. At the same time, the best performance of the mixture in terms of its workability (class SF2) is in SCC mixture with the use of $6 \mathrm{~mm}$ lowmodulus polypropylene fiber and its quantity in the mixture up to $1 \mathrm{~kg}$ per $1 \mathrm{~m}^{3}$, which indicates the possibility of its use in densely reinforced and inaccessible structures. Other mixtures with the size higher than $6 \mathrm{~mm}$ and their content up to $2 \mathrm{~kg}$ per $1 \mathrm{~m}^{3}$ have satisfactory indicators on the workability (class SF1) and accordingly can be recommended for use. It is very important that the mathematical model allows predicting the highest critical content of diversified low-modulus fiber, after which the concrete mixture becomes no longer self-compacting.

One of the main strength indicators of concrete and the target characteristic of our research is bending strength, as the main purpose of fiber application is to improve the characteristics of concrete under bending loads.

According to the results of the conducted tests, which are reflected in the mathematical model of the dependence of bending strength on fiber-reinforcement parameters, it can be assumed that with an increase in the size of the used polypropylene fiber there is an increase in this indicator, which agrees with [27], where it is noted that the decisive factor affecting the bending strength is the content of reinforcing fibers, which have a high flexural resistance, but it should be noted that concrete specimens with a fiber size of $6 \mathrm{~mm}$ and a consumption of $0,5-2 \mathrm{~kg} / \mathrm{m}^{3}$ have bending strength below the control specimen. This is due to the weak anchoring ability of short fibers and the low adhesion index of polypropylene to cement stone, which must be taken into account for further use of polypropylene fibers of this size in SCCs.

From the works of [28] it follows that the highest indicator of bending flexural strength is shown by specimens of concrete with fiber-reinforcement of $12 \mathrm{~mm}$ in size and content of $1.0 \mathrm{~kg} / \mathrm{m}^{3}$, which agrees with the results obtained in this study, where the highest indicators are obtained by concrete with fiber-reinforcement of 12 and $15 \mathrm{~mm}$ in size and content of $1,0-1,5 \mathrm{~kg} / \mathrm{m}^{3}$.

Thus, according to the results of the study it can be stated that the use of a low-modulus polypropylene fiber of a certain size and optimal content is justified in terms of increasing the weakest characteristics of concrete - the flexural strength at bending.

One of the frequent problems encountered at the construction site is the appearance of shrinkage cracks. Due to the fact that SCC is a specific concrete with a high bulk content of cement dough, it had to be proven that using bulk fibre-reinforcement of SCC may reduce the risk of shrinkage cracks. According to the results of the conducted tests and the obtained mathematical dependence of shrinkage deformations of SCC, in comparison with previously published studies in this area [29], in addition to increasing resistance to impact loads, shrinkage cracking of cement stone can be reduced [30].

Microcracks always occur in the curing concrete, and are caused by early forced stresses and own stresses, due to concrete shrinkage or heat removal during hydration of cement. In most cases they occur in the porous contact zone "cement stone/aggregate grain". If the base of the crack hits the fiber, further spreading of the crack for a while is prevented, as the fiber perceives the flexural forces acting on the base of the crack; the crack is stabilized. Since there are many short very thin invisible microcracks, an important factor for effectively preventing the development of such cracks is, first of all, a large number of small diameters fibers. The length of the fibers is of 
secondary importance, since at this stage of crack development there is no relative movement between the fibers and the cement matrix, which is in line with the results of our research, which shows that as the size and content of the fibers increase, there is a general tendency to reduce shrinkage deformations and consequently the probability of crack formation in a fibre-reinforced structure out of SCC decreases. This helps in concluding the following:

- the addition of fibre to SCC mixtures increases the conglomerate's resistance to shrinkage and reduces crack formation;

- the best shrinkage performance was shown by specimens of SCC with a fiber size of $15 \mathrm{~mm}$ and content of $2,0 \mathrm{~kg} / \mathrm{m}^{3}$ (further increase in fiber consumption is unjustified from an economic point of view).

\section{CONCLUSION}

Based on the results of the conducted tests, it can be concluded that the research team has achieved its objectives, in particular the following:

- the effect of fiber-reinforcing parameters on the SCC workability has been studied; the mathematical dependence of rheological properties of highly plastic fiber-concrete mixtures on the size and quantity of lowmodulus polypropylene fiber from the perspective of practical application has been established;

- the experimental estimation of the effect of the size and quantity of the reinforcing fibre on the bending strength was made in order to improve the deformation and operational properties of the concrete working under the corresponding loads, and a mathematical model predicting the bending flexural strength of SCC with the use of bulk fibre-reinforcement was built; the indices of bending strength were achieved $10,5 \%$ higher than those of conventional SCCs of the same class;

- dependencies of drying shrinkage value on fiberreinforcing parameters were determined experimentally and a mathematical model of dependence was built in order to predict the concrete behaviour and control the formation of cracks in sharp-continental dry and hot climate of the Republic of Kazakhstan in summer period (at ambient temperature from 30 to $45^{\circ} \mathrm{C}$ ).

After summarizing and analyzing the results of the conducted tests, it may be concluded that disperse reinforcement of concrete is expedient, i.e. the addition of a certain amount of polypropylene fiber improves the physical-technical and volume change characteristics of existing SCC compositions, in particular, increasing the bending strength and reducing the size of shrinkage deformations. The bulk fibre-reinforcement with lowmodulus polypropylene fibre in SCC mixtures can be recommended for use in production.

Depending on the specific task at hand, factory processors can choose the optimal parameters (in size and volume) for the introduction of low-modulus polypropylene fiber in order to increase one of the three characteristics considered in this paper.

In case of the task of achieving two or three required characteristics at the same time, on the basis of the presented data by a simple variation of these variables the technologist will be able to select the optimum average value of reinforcement (in size and volume). However, here it is necessary to take into account that this average parameter will not allow to receive the best of each required characteristic. For example: compositions reinforced with polypropylene fibre of 12 and $15 \mathrm{~mm}$ in size and amount of $1 \mathrm{~kg}$ have the values of slump flow of $60 \mathrm{~cm}$, which corresponds to the class of workability SF1; the values of bending strength between 5,175 and 5,567 $\mathrm{MPa}$, which is higher than those in control composition up to $10,5 \%$; and the value of shrinkage deformation between $-0,013$ and $-0,067 \mathrm{~mm} / \mathrm{m}$, which is lower than those in control composition up to $343 \%$. These indicators clearly demonstrate the possibility of application and advantages of the volume fiber-reinforcement.

Based on the mathematical dependencies derived, the technologists can form practical recommendations on the optimal choice of size and fiber content in self-compacting concrete to obtain an optimal price-quality ratio, especially when working in the summer.

\section{Acknowledgements}

This research has been funded by the Science Committee of the Ministry of Education and Science of the Republic of Kazakhstan (Grant No. AP05131685).

\section{REFERENCES}

[1] Sfikas, I. (2017). Self-Compacting Concrete: History \& Current Trends. Concrete (London), 51(5), 12-16. Retrieved from:

https://www.researchgate.net/profile/Ioannis_Sfikas/publica tion/317345607_Self-

Compacting_Concrete_History_Current_Trends/links/5936 5d7aa6fdcc89e70e312e-/Self-Compacting-ConcreteHistory-Current-Trends.pdf

[2] Ismail, I., Jamaluddin, N., \& Shahidan, S. (2016). A review on performance of waste materials in self compacting concrete (SCC). Jurnal Teknologi, 78(5). https://doi.org/10.11113/jt.v78.8233

[3] Zhu, W. (2020). Permeation properties of self-compaction concrete. In R. Siddique (Ed.), Self-Compacting Concrete: Materials, Properties and Applications, 117-130. https://doi.org/10.1016/B978-0-12-817369-5.00005-2

[4] Ranjbar, N., Behnia, A., Alsubari, B., Birgani, P. M., \& Jumaat, M. Z. (2016). Durability and mechanical properties of self-compacting concrete incorporating palm oil fuel ash. Journal of Cleaner Production, 112, 723-730. https://doi.org/10.1016/j.jclepro.2015.07.033

[5] Ma, K., Feng, J., Long, G., Xie, Y., \& Chen, X. (2017). Improved mix design method of self-compacting concrete based on coarse aggregate average diameter and slump flow. Construction and Building Materials, 143, 566-573. https://doi.org/10.1016/j.conbuildmat.2017.03.142

[6] Gill, A. S. \& Siddique, R. (2018). Durability properties of self-compacting concrete incorporating metakaolin and rice husk ash. Construction and Building Materials, 176, 323332. https://doi.org/10.1016/j.conbuildmat.2018.05.054

[7] Kaprielov, S. \& Chilin, I. (2013). Ultra High Strength Selfcompacting Fiber Concrete for Monolithic Structures. Construction Materials, (7), 28-30. Retrieved from https://elibrary.ru/item.asp?id=19690896

[8] Ambroise, J., Rols, S., \& Pera, J. (1999). Properties of selflevelling concrete reinforced by steel fibres. In $\mathrm{H}$. W. Reinhardt \& A. E. Naaman (Eds.), Proceedings of the $3 d$ International rILEm Workshop on reinforced cement Composites, $\quad 9-17 . \quad$ Retrieved from 
https://www.rilem.net/publication/publication/11?id papier $=1218$

[9] Utepov, Y., Akhmetov, D., \& Akhmatshaeva, I. (2020). Effect of fine fillers from industrial waste and various chemical additives on the placeability of self-compacting concrete. Computers and Concrete, 25(1), 59-65

[10] Matveyev, D. V., Ivanov, I. M., Chernikh, T. N., \& Kramar, L. Y. (2016). Development and study of self-compacting concrete characteristics using the materials of the Chelyabinsk region. Bulletin of the South Ural State University. Ser. Construction Engineering and Architecture, 16(3), 55-59. https://doi.org/10.14529/build160307

[11] Akhmetov, D. A. (2019). Application of fiber reinforcement in self-compacting concrete. FIBROMIX 2019. Retrieved from https://baltimix.ru/fibromix2019/program/

[12] Opanasenko, E. B. \& Berestianska, A. A. (2015). Types of fiber reinforcement. Resource-Saving Materials, Structures, Buildings and Structures, (30), 57-64. Retrieved from http://www.irbis-nbuv.gov.ua/cgibin/irbis nbuv/cgiirbis 64.exe?I21DBN=LINK\&P21DBN $=\mathrm{UJRN} \& \mathrm{Z} 21 \mathrm{ID}=\& \mathrm{~S} 21 \mathrm{REF}=10 \& \mathrm{~S} 21 \mathrm{CNR}=20 \& \mathrm{~S} 21 \mathrm{STN}=1$ $\& S 21 \mathrm{FMT}=\mathrm{ASP}$ meta $\& \mathrm{C} 21 \mathrm{COM}=\mathrm{S} \& 2 \quad \mathrm{~S} 21 \mathrm{P} 03=\mathrm{FILA}=\&$ 2_S21STR=rmkbs_2015_30_10

[13] Utepov, Y. B., Akhmetov, D. A., Root, Y. N., \& Yermukhanbet, M. A. (2019). Reinforcement of selfcompacting concrete with polypropylene fiber. Bulletin of Civil Engineers, 77(6), 220-227. https://doi.org/10.23968/1999-5571-2019-16-6-220-227

[14] EN 197-1:2011: (2011). Cement - Part 1: Composition, specifications and conformity criteria for common cements. Retrieved from https://www.nlfnorm.cz/en/ehn/24

[15] Interstate standard GOST 30515-2013: (2019). Cements. General specifications. Retrieved from http://docs.cntd.ru/document/1200111314

[16] Interstate standard GOST 310.3-76: (2003). Cements. Methods for determination of standard consistency, times of setting and soundness. Retrieved from http://docs.cntd.ru/document/871001226

[17] Interstate standard GOST 310.4-81: (2003). Cements. Methods of bending and compression strength determination. Retrieved from http://docs.cntd.ru/document/871001227

[18] Interstate standard GOST 8736-2014: (2019). Sand for construction works. Specifications. Retrieved from Standardinform website: http://docs.cntd.ru/document/1200114239

[19] Akhmetov, D. A., \& Root, Y. N. (2017). The experience of using self-compacting concrete in the construction industry of the Republic of Kazakhstan. Young Scientist, (48), 11-14. Retrieved from https://moluch.ru/archive/182/46775/

[20] Interstate standard GOST 8735-88: (1989). Sand for construction work. Testing methods. Retrieved from http://docs.cntd.ru/document/1200003348

[21] Interstate standard GOST 8267-93: (2018). Crushed stone and gravel of solid rocks for construction works. Specifications. Retrieved from http://docs.cntd.ru/document/1200000314

[22] EFNARC. (2002). Specification and guidelines for selfcompacting concrete. European Federation of Specialist Construction Chemicals and Concrete System

[23] Kazancev, A. V. \& Nikolayeva, Y. N. (2018). The effect of fiber reinforcement on the properties of self-compacting concrete mix and concrete. Young Scientist, 17(203), 56-58. Retrieved from https://moluch.ru/archive/203/49677/

[24] Interstate standard GOST 22685-89: (2006). Moulds for making control specimens of concrete. Specifications. Retrieved from http://docs.cntd.ru/document/901705762

[25] Interstate standard GOST 10180-2012: (2018). Concretes. Methods for strength determination using reference specimens. Retrieved from

http://docs.cntd.ru/document/1200100908

[26] Interstate standard GOST 24544-81: (1987). Concretes Methods of shrinkage and creep flow determination. Retrieved from http://docs.cntd.ru/document/9056242

[27] Gutskalov, I. I., Litovchenko, V. V., Zulkarneyev, G. S., \& Medvedev, A. D. (2016). Technological methods for the manufacture of dispersed reinforced fine-grained concrete based on basalt fibers. Young Scientist, 113(9), 125-130. Retrieved from https://moluch.ru/archive/113/29095/

[28] Verevicheva, M. A., Berestyanskaya, A. A., \& Derizemlya, S. B. (2015). Choice of rational parametres of fiber reinforcement. Collection of Scientific Works Construction, Material Sciences, Engineering, (82), 60-82. Retrieved from http://www.irbisnbuv.gov.ua/cgibin/irbis_nbuv/cgiirbis_64. exe?I21DBN=LINK\&P21DBN $=$ UJRN\&Z21ID $=\& S 21 \overline{R E F}$ $=10 \& S 21 \mathrm{CNR}=20 \& \mathrm{~S} 21 \mathrm{STN}=1 \& \mathrm{~S} 21 \mathrm{FMT}=\mathrm{ASP}$ meta\&C 2 $1 \mathrm{COM}=\mathrm{S} \& 2 \_\mathrm{S} 21 \mathrm{P} 03=\mathrm{FILA}=\& 2 \_\mathrm{S} 21 \mathrm{STR}=$ smmit 20158 2 - 11

[29] Agzamov, F. A., Tikhonov, M. A., \& Karimov, I. N. (2013). Research of fibro-reinforces influence on plugging materials properties. Geology, Geophysics, Drilling, 11(2), 30-39. Retrieved from http://ngdelo.ru/files/old_ngdelo/2013/2/ngdelo-2-2013p30-39.pdf

[30] Mesherin, V. (2016). The practical use of fiber, reinforcing textiles and non-metallic bar reinforcement in concrete construction. International Conference and Exhibition of Concrete Technologies ICCX 2016. Retrieved from https://iccx.ru/pdf/ICCX-2016.pdf

\section{Contact information}

Daniyar AKHMETOV, Dr. Tech. Sc

NIISTROMPROJECT, LLP,

Almaty, Radostovec str.,152/6, office109, 110,

050000, Almaty, Kazakhstan

E-mail: dan-akhmetov@yandex.kz

Aleksej ANISKIN, PhD, Assistant professor

Department of Civil Engineering, University North,

Jurja Križanića 31b, 42000 Varaždin, Croatia

E-mail: aaniskin@unin.hr

Yelbek UTEPOV, PhD, Associate professor

(Corresponding author)

Department of Civil Engineering, L.N. Gumilyov Eurasian National University,

Satpayev Str., 2, 010008, Nur-Sultan, Kazakhstan

E-mail: utepov-elbek@mail.ru

\section{Yelena ROOT, MSC}

NIISTROMPROJECT, LLP,

Almaty, Radostovec str.,152/6, office109, 110,

050000, Almaty, Kazakhstan

E-mail: elenaroot.niistrom@gmail.com

Goran KOZINA, PhD, Full Professor

University North,

Jurja Križanića 31b, 42000 Varaždin, Croatia

E-mail: goran.kozina@unin.hr 